\title{
Mystery Case: Pontine tegmental cap dysplasia in a neonate
}

Neslihan Bilgin, MD, Safak Parlak, MD, Pelin Özlem Şimşek-Kiper, MD, PhD, Meral Topcu, MD, and Haluk Topaloglu, MD

Neurology ${ }^{\circledR}$ 2018;91:e2100-e2101. doi:10.1212/WNL.0000000000006578

\author{
Correspondence \\ Dr. Topaloglu \\ htopalog@hacettepe.edu.tr
}

Figure 1 Cranial MRI of the neonate

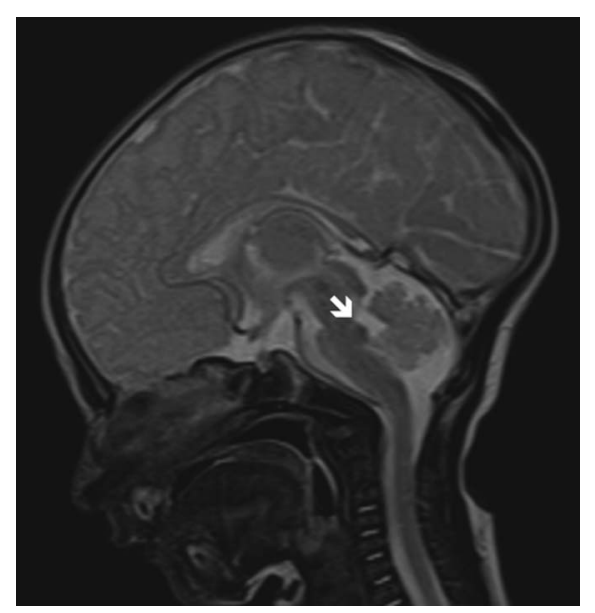

Midsagittal T2-weighted image (repetition time/echo time 3,600/100 ms) of the patient at her 13th day shows flattening of the ventral pons and dysmorphism of the dorsal upper pons (caplike) protruding in the fourth ventricle (white arrow).

A 2-month-old girl with swallowing difficulty initiated at day 1 was evaluated. Birth history was unremarkable. Her suck, Moro, and grasp reflexes were normal; however, she could not swallow. She had soft palate sagging. She had hearing impairment in her right ear. Basic biochemistry, metabolic tests, and karyotype and microarray studies were normal.

A cranial MRI on day 13 showed tegmental cap (figures 1 and 2). Tegmental cap is a congenital hind brain anomaly with developmental delay, oculomotor disturbances, facial involvement, sensorineural deafness, and swallowing difficulty. Neuroimaging is diagnostic with flat ventral pons, an abnormal curved structure of the pontine tegmentum projecting into the fourth ventricle, and varying degrees of cerebellar peduncle anomalies. Failure of axonal guidance in utero is the most likely pathophysiology. ${ }^{1,2}$

\section{Author contributions}

N. Bilgin performed acquisition of data. Ş. Parlak performed analysis and interpretation. P.Ö. Şimşek-Kiper performed acquisition of data. M. Topçu performed study supervision. $\mathrm{H}$. Topaloğlu performed critical revision of the manuscript.

\section{Study funding}

No targeted funding reported.

\section{Survey and results}

NPub.org/mc9122

From the Departments of Pediatric Neurology (N.B., M.T., H.T.) and Pediatric Genetics (P.O.S.-K.), Hacettepe University Ihsan Dogramaci Children's Hospital; and Department of Radiology (S.P.), Hacettepe University Hospitals, Ankara, Turkey.

Go to Neurology.org/N for full disclosures. Funding information and disclosures deemed relevant by the authors, if any, are provided at the end of the article. 
Figure 2 Cranial MRI of the neonate

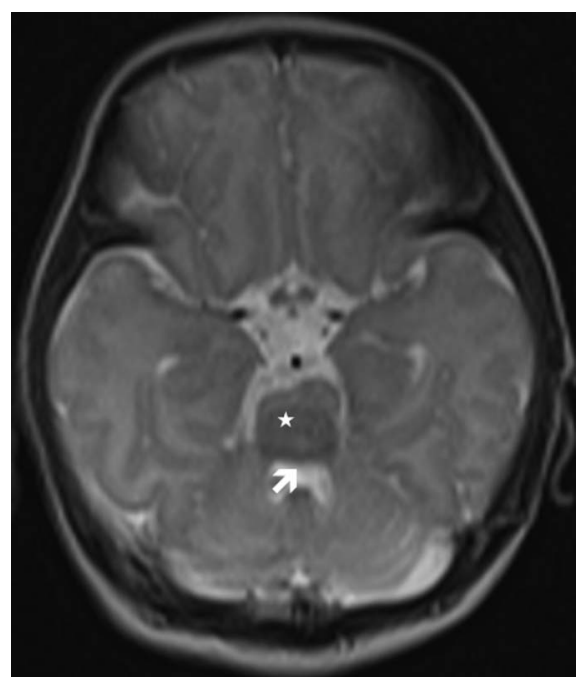

Axial T2-weighted image at the level of midpons. The white star indicates asymmetrically thin right side of the pons. White arrow shows the tegmental cap.

\section{Disclosure}

The authors report no disclosures relevant to the manuscript. Go to Neurology.org/ $\mathrm{N}$ for full disclosures.

\section{References}

1. Barth PG, Chalers BM, Matthan WA, et al. Pontine tegmental cap dysplasia: a novel brain malformation with a defect in axonal guidance. Brain 2007;130:2258-2266.

2. Picker-Minh S, Hartenstein S, Proquitte H, et al. Pontine tegmental cap dysplasia in an extremely preterm infant and review of the literature. J Child Neurol 2017;32:334-340.

\section{Mystery Case responses: A 2-month-old girl with difficulty swallowing}

The Mystery Case series was initiated by the Neurology ${ }^{\circledR}$ Resident \& Fellow Section to develop the clinical reasoning skills of trainees. Residency programs, medical student preceptors, and individuals were invited to use this Mystery Case as an educational tool. Responses to multiple choice questions formulated using this case were solicited through a group email sent to the American Academy of Neurology Consortium of Neurology Residents and Fellows and through social media. We received 145 responses. The majority of respondents
(75\%) had been in practice for $1-4$ years; $57 \%$ were residents or fellows and $31 \%$ were faculty/board-certified physicians; the remainder were medical students or advanced practice providers. Sixty-two percent resided outside the United States. A wide range of practice settings was represented.

When presented with this 2-month-old patient's history and examination findings and shown the representative T2 MRI brain slices, 39\% correctly identified the thin right side of the pons, $26 \%$ also identified flattening of the ventral pons, while only $13 \%$ also recognized the protrusion of the dorsal pons. The most frequently selected incorrect options were agenesis of the corpus callosum (55\%) and of the cerebellar vermis (28\%); the cuts presented were perhaps not ideal for visualizing these structures, but these were not the evident abnormalities.

Upon then being asked to select the most likely diagnosis based on these findings, $16 \%$ correctly selected pontine tegmental cap dysplasia. The most popular but incorrect choices were olivopontocerebellar atrophy (19\%) and pontocerebellar hypoplasia type 2 (17\%). Pontocerebellar hypoplasia is a group of progressive degenerative diseases that begin prenatally and continue postnatally and involve not only the cerebellar system but also have extensive cortical and basal ganglionic abnormalities even in motor neurons, causing a clinical presentation at birth that can resemble spinal muscular trophy. ${ }^{1}$ Olivopontocerebellar hypotrophy, on the other hand, is not a developmental disorder of the nervous system but rather a form of multisystem atrophy characterized by predominant cerebellar features.

This pediatric neurology case highlights an important developmental abnormality of the nervous system and also demonstrates the value of carefully reviewing midline structures on neuroimaging.

Aravind Ganesh, MD

Department of Clinical Neurosciences, University of Calgary, Canada; Centre for Prevention of Stroke and Dementia, University of Oxford, UK.

\section{Reference}

1. Sarnat HB, Flores-Sarnat L. Developmental disorders of the nervous system. In: Daroff RB, Jankovic J, Mazziotta JC, Pomeroy SL, eds. Bradley's Neurology in Clinical Practice, 7th ed, volume I. London: Elsevier; 2016:1279-1300. 


\section{Neurology}

\section{Mystery Case: Pontine tegmental cap dysplasia in a neonate \\ Neslihan Bilgin, Safak Parlak, Pelin Özlem Simsek-Kiper, et al. \\ Neurology 2018;91; 2100-e2101 \\ DOI 10.1212/WNL.0000000000006578}

This information is current as of November 26, 2018

Updated Information \& Services

References

Subspecialty Collections

Permissions \& Licensing

Reprints including high resolution figures, can be found at: http://n.neurology.org/content/91/22/e2100.full

This article cites 3 articles, 0 of which you can access for free at: http://n.neurology.org/content/91/22/e2100.full\#ref-list-1

This article, along with others on similar topics, appears in the following collection(s):

MRI

http://n.neurology.org/cgi/collection/mri

Neonatal

http://n.neurology.org/cgi/collection/neonatal

Information about reproducing this article in parts (figures,tables) or in its entirety can be found online at:

http://www.neurology.org/about/about_the_journal\#permissions

Information about ordering reprints can be found online:

http://n.neurology.org/subscribers/advertise

Neurology ${ }^{\circledR}$ is the official journal of the American Academy of Neurology. Published continuously since 1951 , it is now a weekly with 48 issues per year. Copyright @ 2018 American Academy of Neurology. All rights reserved. Print ISSN: 0028-3878. Online ISSN: 1526-632X.

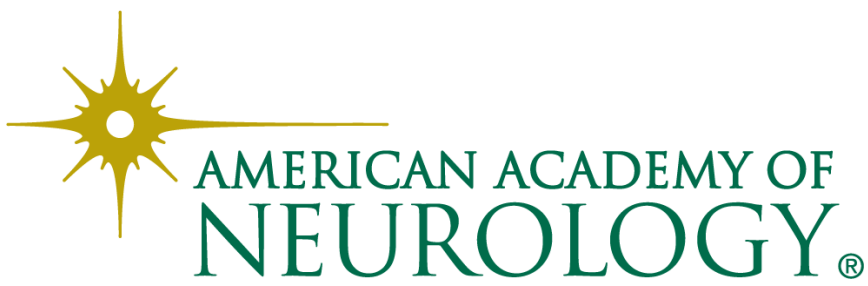

